\section{ECONOMICS}

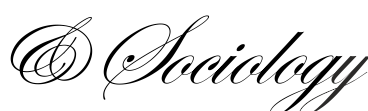

Galnaitytė, A., Kriščiukaitienė, I., Baležentis, T., Namiotko, V. (2017). Evaluation

of Technological, Economic and Social Indicators for Different Farming

Practices in Lithuania. Economics and Sociology, 10(4), 189-202. doi:10.14254/2071789X.2017/10-4/15

\title{
EVALUATION OF TECHNOLOGICAL, ECONOMIC AND SOCIAL INDICATORS OF DIFFERENT FARMING PRACTICES IN LITHUANIA
}

\author{
Aistė Galnaitytè, \\ Lithuanian Institute of Agrarian \\ Economics, \\ Vilnius, Lithuania, \\ E-mail:aiste@laei.lt \\ Irena Kriščiukaitienè, \\ Lithuanian Institute of Agrarian \\ Economics, \\ Vilnius, Lithuania, \\ E-mail:irena@laei.lt \\ Tomas Baležentis, \\ Lithuanian Institute of Agrarian \\ Economics, \\ Vilnius, Lithuania, \\ E-mail:tomas@laei.lt \\ Virginia Namiotko, \\ Lithuanian Institute of Agrarian \\ Economics, \\ Vilnius, Lithuania, \\ E-mail:virginia@laei.lt \\ Received: May, 2017 \\ 1st Revision: June, 2017 \\ Accepted: November, 2017 \\ DOI: $10.14254 / 2071-$ \\ 789X.2017/10-4/15
}

\begin{abstract}
Organic and integrated farming practices contribute to protecting biodiversity, reducing environmental pollution, improving soil quality, and providing high-quality raw material for food industry. The objective of the article is to establish the methodology and evaluate the system of indicators, which enables answering the question which farming practice has more advantages: organic or integrated? Multi-criteria analysis methods were used to achieve this objective. When being compared with between conventional and integrated farming practices, organic farming practice achieves higher profitability and greater energy efficiency. Organic farming reveals to be either superior, or similar to integrated farming practices in environmental terms. Potatoes, fruits and berries under both conventional and integrated farming practices have obtained the same rank (1-2) according to the selected criterions (yield, share of sold product, expenses on plant protection, production cost, price and labour input). Organic farming practice has shown worse rank. Organic farming practice has appeared to be the most suitable for vegetables.
\end{abstract}

JEL Classification:C44, Q15, Q18

Keywords: integrated farming practices; Lithuania; multi-criteria analysis; organic farming practices.

\section{Introduction}

Current trends in agriculture development are focused not only on economic performance, but also on the consequences of corporate activities for the environment and sustainabality (Rajnoha, Lesníkova, 2016; Balas, 2014; Czyżewski, Smędzik-Ambroży, 2015). 
In terms of sustainability there are two main farming practices in Lithuania being practiced in recent years: organic and integrated farming. Organic farming encourages the increasing supply of valuable crop production, protecting biodiversity, reducing environmental pollution, and improving soil quality. Integrated farming practice aims to encourage farmers who grow fruits, berries and vegetables, to introduce environmentally friendly production techniques so that to reduce environmental pollution (Rural Development Programme, 2017). Both these farming practices are important for consumers because they provide high-quality raw material for food industry. But both agricultural producers and policy-makers raise the question which of these farming practices is more relevant in terms of sustainability. Thus, a research problem emerges concerning how to evaluate, determine and compare technological, economic and social indicators of organic and integrated farming practices.

The practical relevance of this article is that it is pursuing to adopt research-grounded policy decisions. Therefore, it is essential to develop and apply the assessment methodology based on quantitative and qualitative methods, leading to further assessment of the potential impacts from organic and integrated farming practices.

The objective of this article is to create the methodology and evaluate the system of indicators, which would enable answering the question which farming practice has more advantages: organic or integrated? Intense competition is being currently observed between these sectors in agriculture. It is worth also noting that the economic issues behind comparing the farming practices in Lithuania are yet not explored.

The object of this research is sustainable farming practices.

Referring to the economy of ecosystems and the results of the research, considering agricultural production technologies and the requirements to organic and integrated farming practices, an integrated set of data was compiled, covering technological, economic and environmental indicators. Multi-criteria analysis methods were used to achieve the objective posed in this article.

\section{Literature review}

Scientific discussion concerning the most appropriate farming practices in terms of sustainability has become significant among policy decision makers and practitioners in recent years. Organic farming practices is well known and considered as a promising option to sustain both agriculture productivity and environment (Delmotte et al., 2016; Jouzi et al., 2016; Kirchmann et al., 2016; Tasca, 2017; Balezentis, 2014). Organic farming offers innovative conservation agriculture principles, including minimal soil disturbance (reduced tillage, no-tillage, green manures), permanent soil cover and long crop rotation mean duration of six years (Peigne et al., 2016). This helps to reduce use of mineral fertilizers, control weeds without the use of herbicides, without losses of yield. Organic farming is more energy efficient compare to conventional almost for all types of crops when expressed on a unit of area. Results are more variable per unit of product because of lower organic yields (Smith $e t$ al., 2015). Although organic agriculture produces lower yields than conventional agriculture, it better unites human health, environment and socioeconomic objectives than conventional farming practice (Crowder, Reganold, 2015; Streimikiene, Bilan, 2015).

The evaluation of the economic and environmental trade-offs between different farming practices revealed that the gross margins of organic farming practices were found to be higher than the corresponding conventional farming practices gross margins. Organic farming practices perform better than integrated farming practices and conventional farming practices with respect to nitrogen losses, pesticide risk, herbaceous plant biodiversity and most of the other environmental indicators. Considering the regional and site-specific soil and 
climate conditions on the environmental performances of the farming practices it was observed that on hilly soils, erosion was higher in organic farming practices than in conventional farming practices. The pesticide and the nitrogen indicators showed a similar environmental impact caused by integrated and conventional farming practices (Pacini et al., 2003). For organic farming practice, as a consequence, some production factors are used less efficiently, thus partly negating the advantages of organic farming. Furthermore, the different manure management strategy leads to relatively high nutrient losses in relation to yield. These two points were shown to be the main priorities for the environmental optimisation of organic farming practice (Nemecek et al., 2011).

Escalating production costs, heavy reliance on non-renewable resources, reduced biodiversity, water contamination, chemical residues in food, soil degradation and health risks to farmworkers handling pesticides all bring into question the sustainability of conventional farming practice. The organic farming practises are less efficient, pose greater health risks and produce half the yields of conventional farming practice. Nevertheless, organic farming became one of the fastest growing segments of agriculture in the United States of America and European Union (EU). Integrated farming, using a combination of organic and conventional techniques, has been successfully adopted on a wide scale in Europe (Reiff et al., 2016). Comparative analysis carried out by Reganold et al. (2001) on sustainability of organic, conventional and integrated apple production systems gave similar apple yields and showed that organic and integrated practices had higher soil quality and potentially lower negative environmental impact than the conventional farming practice. When compared with the conventional and integrated farming practices, the organic farming practice produced higher profitability and greater energy efficiency. The organic farming practice ranked first in environmental and economic sustainability, the integrated farming practice second and the conventional farming practice last (Reganold et al., 2001).

In the overall assessment organic farming was revealed to be either superior or similar to integrated farming practices in environmental terms. Integrated farming practice, which is the base of the "Environmentally friendly fruits and vegetables cultivation system", according to the scientists within the field of ecology and environment (Kirchmann, Bergstrom, 2008; Posner et al., 2008), is one of the most promising and advisable activities to apply in the agricultural sector.

Organic farming has its main strengths in better resource conservation, since the farming practice relies mainly on farm-internal resources and limits the input of external auxiliary materials. This results in less fossil and mineral resources being consumed. Moreover the greatly restricted use of pesticides makes it possible to markedly reduce ecotoxicity potentials on the one hand, and to achieve a higher biodiversity potential on the other. This overall positive assessment is not valid for all organic products: some products such as potatoes had higher environmental burdens than their counterparts from integrated farming practices (Nemecek et al., 2011). After the literature review, it can be concluded that, all the authors recognizes that both organic and integrated farming practices are appropriate for the policy sustainability goals implementation. However, most authors prefer organic farming.

\section{Methodological approach}

The methodology for the evaluation of organic and integrated farming practices using technological, economic and social indicators, was created according principles as recommended in the scientific literature (Giupponi et al., 2012; Balana et al., 2011).

Multi-criteria methods have been used for quantitative evaluation of complex phenomena (Zavadskas et al., 2009; Žvirblis, Buračas, 2010; Baležentis, 2016; Baležentis et 
al., 2017; Craheix et al., 2016; Petit, Aubry, 2016; De Luca et al., 2017; Kamali et al., 2017). Multi-criteria methods integrate the values of the criteria describing a particular process and their weights into a single value. However, all of these methods are based on different logical principles, have different complexity levels and the inherent features. Therefore, it is recommended to use of several methods and average of the values obtained (Krisciukaitiene et al., 2015). SAW, COPRAS, TOPSIS and VIKOR methods were used to fulfil the objective of the article. Multi-criteria methods are based on the matrix $R=\left\|r_{i j}\right\|$ of the criteria, explaining the objects $A_{j}(j=1,2, \ldots, n)$ compared, statistical data and the criteria weights $\omega_{i}(i=1,2, \ldots, m)$, where $m$ is the number of criteria and $n$ is the number of objects compared. The criteria weights were determined by the authors after the consultations with the experts of the Lithuanian Institute of Agrarian Economics.

SAW (Simple Additive Weighting) method is one of the most widely used methods for multi-criteria evaluation (Hwang, Yoon, 1981; Ustinovičius, Zavadskas, 2004; Rozman et al., 2016; Vico, 2017).

The criterion of the method $S_{j}$ was calculated by the formula:

$$
S_{j}=\sum_{i=1}^{m} \omega_{i} \widetilde{l_{l j}}
$$

where $\omega_{i}$ is the weight of the $i$-th criterion, $\widetilde{r_{l j}}$ is the normalized $i$-th criterion's value for $j$-th alternative.

The criterion of COPRAS (Complex Proportional Assessment) method $Z_{j}$ was obtained by the formula:

$$
Z_{j}=S_{+j}+\frac{S_{-\min } \sum_{j=1}^{n} S_{-j}}{S_{-j} \sum_{j=1}^{n} \frac{S_{-\min }}{S_{-j}}},
$$

where $S_{+j}$ is the sum of maximizing weighted normalized criteria values:

$$
S_{+j}=\sum_{i=1}^{m} d_{+i j}
$$

$S_{-j}$ is the sum of minimizing weighted normalized criteria values:

$$
S_{-j}=\sum_{i=1}^{m} d_{-i j}
$$

$S_{-\min }$ is the minimal $S_{-j}$ value of minimizing criteria of all alternatives.

Using TOPSIS (Technique for Order Preference by Similarity to an Ideal Solution) (Hwang, Yoon, 1981; Manos, 2016) method the ideal and negative-ideal solutions were determined by formulas:

$$
V^{*}=\left\{V_{1}^{*}, V_{2}^{*}, \ldots, V_{m}^{*}\right\}=\left\{\left(\max _{j} \frac{\omega_{i} \tilde{r}_{i j}}{i} \in I_{1}\right),\left(\min _{j} \frac{\omega_{i} \tilde{r}_{i j}}{i} \in I_{2}\right)\right\},
$$




$$
V^{-}=\left\{V_{1}^{-}, V_{2}^{-}, \ldots, V_{m}^{-}\right\}=\left\{\left(\min _{j} \frac{\omega_{i} \tilde{r}_{i j}}{i} \in I_{1}\right),\left(\max _{j} \frac{\omega_{i} \tilde{r}_{i j}}{i} \in I_{2}\right)\right\}
$$

where $I_{1}$ is associated with benefit criteria, $I_{2}$ is associated with cost criteria.

The criterion of the method $C_{j}^{*}$ is calculated by the formula:

$$
C_{j}^{*}=\frac{D_{j}^{-}}{D_{j}^{*}+D_{j}^{-}}
$$

where $D_{j}^{*}$ is the separation of each alternative from ideal solution:

$$
D_{j}^{*}=\sqrt{\sum_{i=1}^{m}\left(\omega_{i} \tilde{r}_{i j}-V_{i}^{*}\right)^{2}} .
$$

$D_{j}^{-}$is the separation from negative-ideal solution:

$$
D_{j}^{-}=\sqrt{\sum_{i=1}^{m}\left(\omega_{i} \tilde{r}_{i j}-V_{i}^{-}\right)^{2}} .
$$

The compromise ranking algorithm VIKOR (serb. VlseKriterijumska Optimizacija I Kompromisno Resenje) was calculated by the following steps: 1) determine the ideal $f_{i}^{*}$ and negative-ideal $f_{i}^{-}$values of all criterion functions; 2) compute the values $S_{j}$ and $R_{j}$ for each alternative:

$$
\begin{gathered}
S_{j}=\sum_{i=1}^{n} \frac{\omega_{i}\left(f_{i}^{*}-f_{i j}\right)}{\left(f_{i}^{*}-f_{i}^{-}\right)}, \\
R_{j}=\max _{i}\left[\omega_{i}\left(f_{i}^{*}-f_{i j}\right) /\left(f_{i}^{*}-f_{i}^{-}\right)\right],
\end{gathered}
$$

where $\omega_{i}$ is the weight of the $i$-th criterion; and 3) compute the values $Q_{j}$ :

$$
Q_{j}=v \frac{S_{j}-S^{*}}{S^{-}-S^{*}}+(1-v) \frac{R_{j}-R^{*}}{R^{-}-R^{*}}
$$

where $S^{*}=\min _{j} S_{j}, S^{-}=\max _{j} S_{j}, R^{*}=\min _{j} R_{j}, R^{-}=\max _{j} R_{j}, v$ is the weight of the strategy of "the majority of criteria" (or "the maximum group utility") and usually set to 0.5 (Opricovic, Tzeng, 2004; Manos, 2016).

Conventional, organic and integrated farming practices were used to compare their indicators for those crops: potatoes, vegetables, fruits and berries.

After the literature review the main indicators to compare above mentioned farming practices were selected and outlined in the section below. Three indicators - labour input, hours/ha per year; agricultural production costs, EUR/t; and expenses for plant protection, EUR/ha - were minimizing while yield of agricultural crops, t/ha; purchasing price of 
agricultural production, EUR/t; and share of sold production, per cent were maximizing. It is worth to mention, that compensatory payments are very important indicator, but it is not included in to the indicators system, because they compensate additional costs and/or income foregone due to the commitment given and could not influence evaluation results. Data was collected from Eurostat, Statistics Lithuania, Lithuanian Institute of Agrarian Economics, the Ministry of Agriculture of the Republic of Lithuania and Agricultural Information and Rural Business Centre data bases.

\section{Conducted research and results}

Rationale and assessment results of technological, economic and social indicators of organic and integrated farming practices are outlined in this section.

\subsection{Rationale of organic and integrated farming practices}

Organic farming practice occupies an essential place in Lithuania because it started more than two decades ago and has the tendency to increase particularly after the accession to the EU. Utilized agricultural area (UAA) under the organic farming has increased about one third during last five years and reached 214 thous. hectares in 2016. This increase was caused by comparatively high support under the "Organic farming" measure starting from 2004 to convert or maintain organic farming practices and methods (EU Regulation, 2013). The organic farming practice contributes to the needs in solving problems related to the high quality food supply and sustainable farming practices development (Rural Development Programme, 2017). Support for organic farming also solve the problems related to the negative environmental impact mitigation, biodiversity conservation and ecosystem stability maintenance, because organically farming farmers promote environmentally friendly farming, introduce nature conserving technologies and complies agri-environmental requirements (Rural Development Programme, 2017).

The integrated farming practice aims to preserve the necessary changes to agricultural practices that make a positive contribution to the environment and climate (EU Regulation, 2013). It is relatively new in Lithuania (from 2012), when support under the activity "Environmentally friendly fruits and vegetables cultivation system" was started. Activity implementation results show permanent increase of UAA, doubled during 2012-2016 up to 5 thous. hectares. Implementation of the integrated farming practices is still insufficiently widespread. The results could be much better if more crops (not only vegetables, potatoes, fruits and berries) are involved in to this activity. On the other hand, it would lead to higher demand of financial funds, which are insufficient in recent years. 


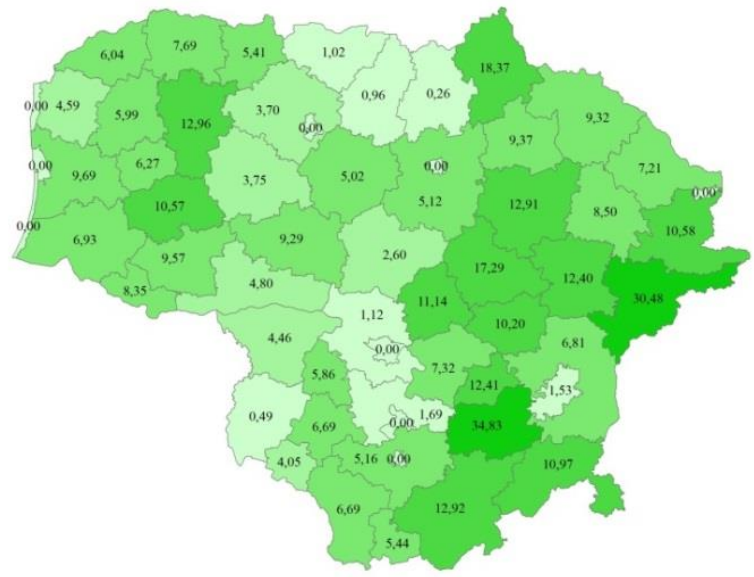

a)

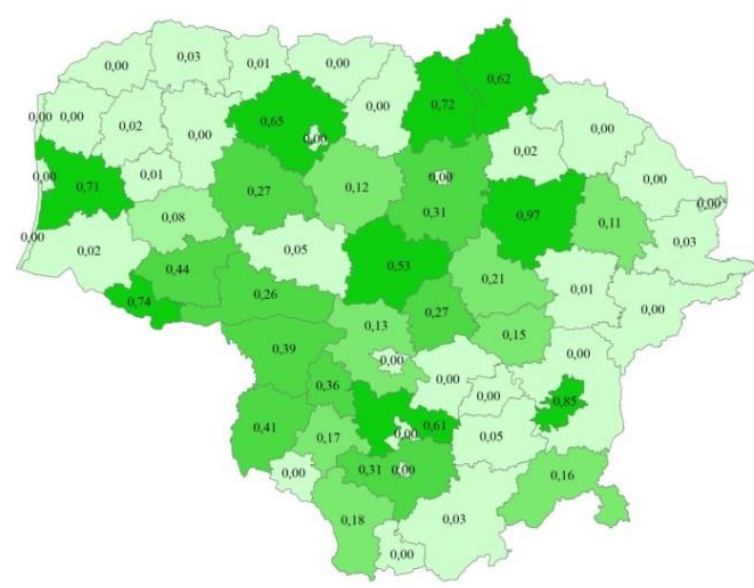

b)

Graph 1. Share of the total utilized agricultural area declared across municipalities under: a) the "Organic farming" measure, b) the activity "Environmentally friendly fruits and vegetables cultivation system" of the measure "Agri-environment payments" in 2016.

Source: composed using data from the Agricultural Information and Rural Business Centre in Lithuania (Informacija, 2016).

The question is which of the farming methods discussed has more advantages: integrated or organic? At the moment competition between these two farming practices is observed. In response to a question, more attention has to be focused on the production levels prediction and monitoring with the purpose to justify the expectations of consumers.

Spatial analysis shows that integrated farming is concentrated in central part of Lithuania, where farming conditions are better, but only in few municipalities (Graph 1). In contrary, organic farming is cultivated in all the municipalities and occupies larger share of UAA compare to integrated farming. The problem arises that organic farming is spread in those areas with low land quality and is not able to produce sufficient yields. The main reasons of this disproportionate distribution are different economic conditions (public support and production cost) for organic and integrated farming.

\subsection{Assessment of technological, economic and social indicators}

Evaluating of organic and integrated farming practices according to scientific literature technological, economic and social indicators were chosen. The following indicators were included into multi-criteria analysis: technological (yield, share of sold production) (Balana et al., 2011; Uthes et al., 2011; Sauer et al., 2012; Dzikowski, 2013), environmental (expenses for plant protection) (Kriščiukaitienè et al., 2013); economic (production cost, price) (Blanco Fonseca, 2007; Acs et al., 2010; Udagawa et al., 2014); and social (labour input) (Blanco Fonseca, 2007).

Traditionally, potatoes, vegetables and orchards are cultivated under the conventional farming practices: area occupies 98, 95 and 90 percent of total UAA respectively. In contrary, berry plantations mostly are cultivated under the organic farming practices, area occupies 48 percent of total UAA, followed by integrated ( 28 percent) and conventional ( 24 percent) farming practices. The reasons are mainly related to higher profitability farming conventionally.

Analysing separate indicators it is worth to conclude that technological indicators yields are highest for all analysed products under conventional farming practices. However, 
share of sold production is slightly higher under integrated farming practices (Graph 2). Environmental indicator - expenses for plant protection - differs depending on the product: the lowest expenses for potatoes are observed in organic farming, while highest - in conventional. There are no expenses for plant protection for organic vegetables, while conventional and integrated farming shows similar expenses. In opposite, for organic fruits and berries expenses for plant protection are higher than for conventional and integrated, because plant protection means allowed in organic farming for fruits and berries are more expensive, but also are more environment friendly. The question which farming practices supply more safe products could be answered by technological research.

Potatoes profitability without support is the highest (42 percent) and differs from integrated by 14 percentage points. Organic farming appears unprofitable without support for many years. The economic situation with support is observed slightly different: the most profitable becomes integrated potatoes farming and organic potatoes' farming becomes profitable too; however with the lowest profitability among the practices analysed. Profitability of the vegetables differs insignificantly under all the practices - organic shows the lowest ratio. On the other hand, organic vegetable farming is the most environment friendly and supply safe products, because does not use chemical plant protection means. Fruit profitability without support also is highest under the conventional farming. If compared the conventional, organic and integrated farming practices with support profitability differs insignificantly. Profitability without support of the berries differs insignificantly under all the practices, however with support becomes highest under the organic farming due to higher prices and lower costs in comparison with conventional and integrated farming practices.

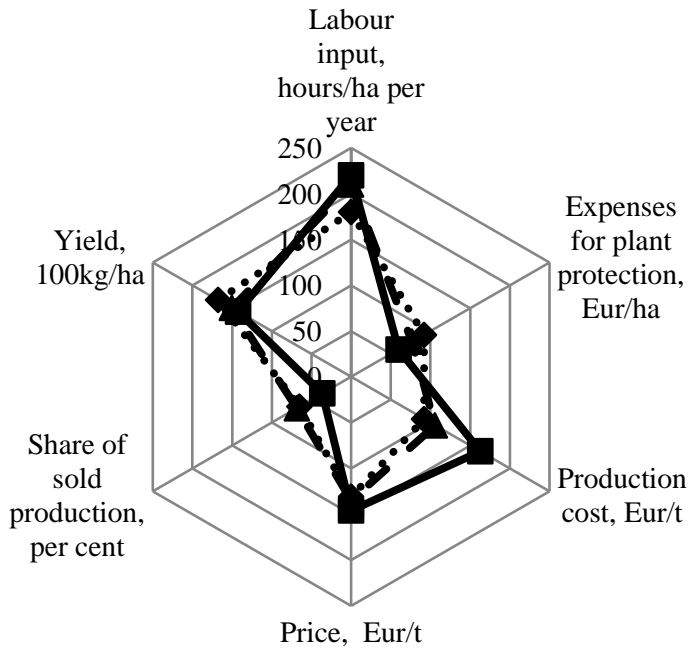

•.•.. Conventional $\longrightarrow$ Organic $\longrightarrow \Delta$ Integrated

Potatoes

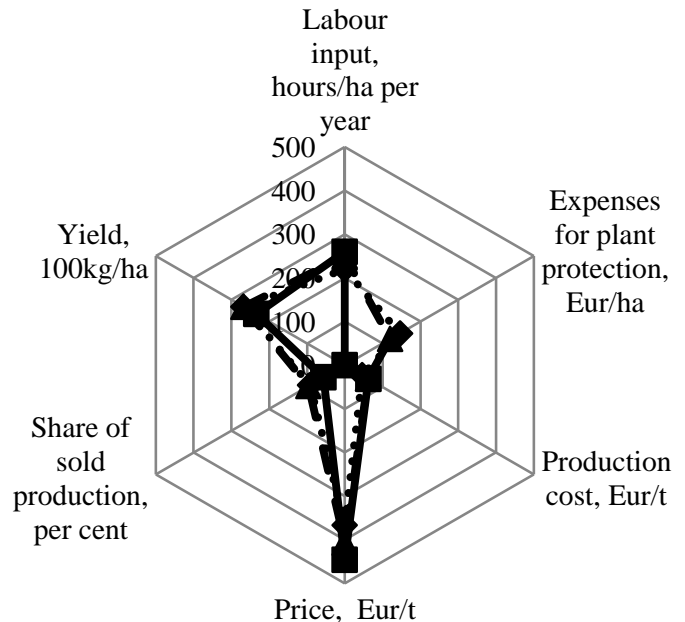

Price, Eur/t

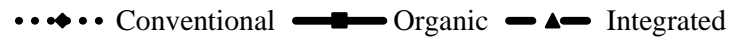

Vegetables 


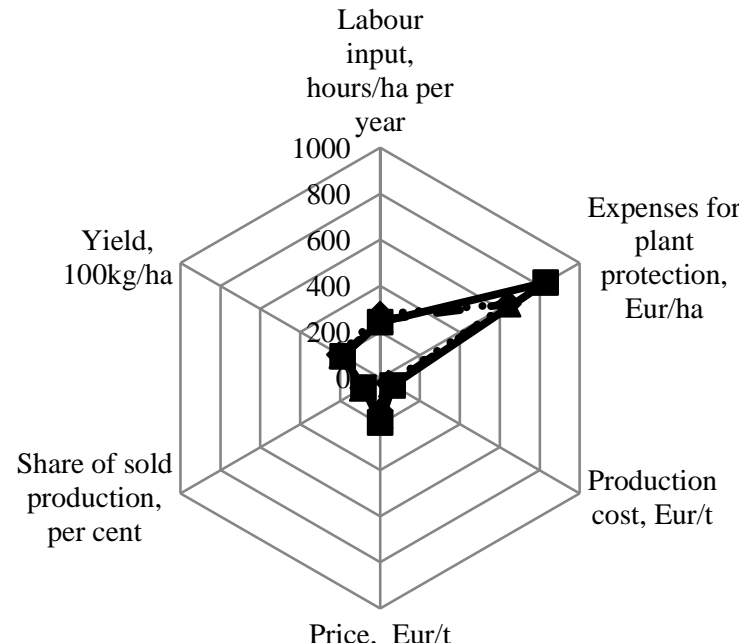

Price, Eur/t

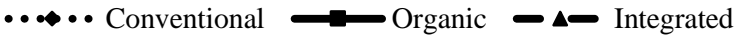

Fruits

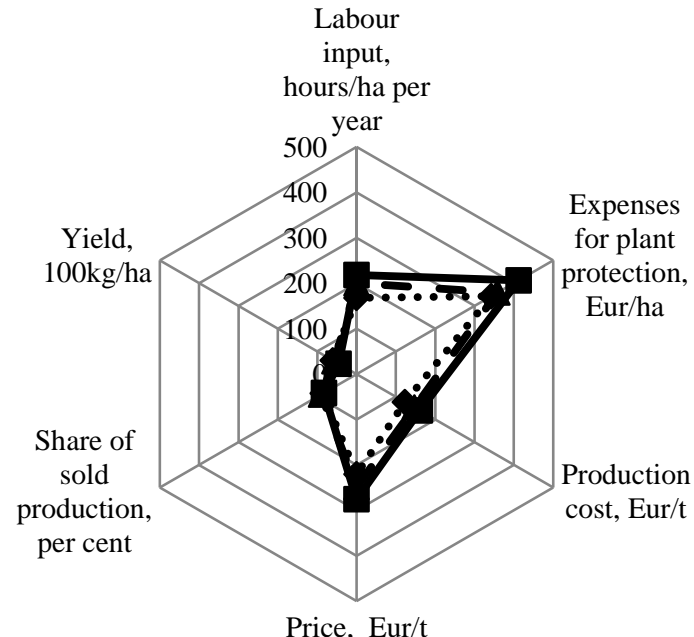

$\cdots \bullet$ Conventional $\longrightarrow$ Organic $\longrightarrow \Delta$ Integrated

Berries

Graph 2. Comparison of production, economic and social indicators for different farming practices in Lithuania

Source: composed using data from the Lithuanian Institute of Agrarian Economics (Kriščiukaitienè, 2013), Statistics Lithuania (Lietuvos žemès, 2016), and Eurostat (2017).

Economic indicators such as production costs are observed highest for all products under the organic farming practice and lowest under conventional, while prices show opposite means. Social indicator, such as labour input for potatoes, vegetables and berries is highest under the organic farming practice because of additional labour needs for weed control. Only for organic fruits production labour input is lowest due to lower yields. Such a differences in separate indicators evaluation highly demands for multi-criteria analysis in terms of sustainability. For this purpose as suggested in scientific literature few multi-criteria analysis methods were used: SAW, COPRAS, TOPSIS and VIKOR. Practical benefit, on the one hand, is for policy makers to improve agri-environmental measures and, on the other hand, for farmers to understand and to decide when choosing farming practices to adapt.

The ranks of the farming practices of four different crops are presented by four above mentioned methods differ insignificantly (Table 1).

Table 1. Assessment results of farming practices of different crops in 2015.

\begin{tabular}{lccccccccc}
\hline \multirow{2}{*}{$\begin{array}{c}\text { Farming } \\
\text { practices }\end{array}$} & \multicolumn{2}{c}{ SAW } & \multicolumn{2}{c}{ COPRAS } & \multicolumn{2}{c}{ TOPSIS } & \multicolumn{2}{c}{ VIKOR } & Final \\
\cline { 2 - 11 } \multicolumn{1}{c}{1} & Value & Rank & Value & Rank & Value & Rank & Value & Rank & rank \\
\hline & 2 & 3 & 4 & 5 & 6 & 7 & 8 & 9 & 10 \\
\hline Conventional & .900 & 1 & .349 & 2 & .638 & 2 & .500 & 2 & 2 \\
\hline Organic & .786 & 3 & .300 & 3 & .349 & 3 & .000 & 3 & 3 \\
\hline Integrated & .890 & 2 & .352 & 1 & .729 & 1 & .957 & 1 & 1 \\
\hline & & & \multicolumn{7}{c}{ Vegetables } \\
\hline Conventional & .756 & 2 & .303 & 3 & .282 & 3 & .500 & 2 & 3 \\
\hline Organic & .836 & 1 & .386 & 1 & .703 & 1 & .000 & 3 & 1 \\
\hline Integrated & .720 & 3 & .311 & 2 & .326 & 2 & .699 & 1 & 2 \\
\hline
\end{tabular}


INTERDISCIPLINARY APPROACH TO ECONOMICS AND SOCIOLOGY

\begin{tabular}{|c|c|c|c|c|c|c|c|c|c|}
\hline 1 & 2 & 3 & 4 & 5 & 6 & 7 & 8 & 9 & 10 \\
\hline \multicolumn{10}{|c|}{ Fruits } \\
\hline Conventional & .997 & 1 & .343 & 1 & .600 & 1 & .413 & 2 & 1 \\
\hline Organic & .926 & 3 & .320 & 3 & .394 & 3 & .000 & 3 & 3 \\
\hline Integrated & .983 & 2 & .337 & 2 & .521 & 2 & 1.000 & 1 & 2 \\
\hline \multicolumn{10}{|c|}{ Berries } \\
\hline Conventional & .992 & 1 & .350 & 1 & .625 & 1 & .500 & 2 & 1 \\
\hline Organic & .889 & 3 & .314 & 3 & .365 & 3 & .000 & 3 & 3 \\
\hline Integrated & .956 & 2 & .336 & 2 & .532 & 2 & .954 & 1 & 2 \\
\hline
\end{tabular}

Source: own calculations.

Three of for multi-criteria analysis methods show, that for potatoes mostly suits integrated farming practice. The second choice according the results obtained could be conventional farming practices. The organic farming becomes attractive for the farmers when potatoes yields and quality will increase and consumers will be able and agree to pay higher price for organic potatoes.

Concerning the vegetables according all the methods with exception of VIKOR due to the first place belongs to organic farming practice. The second place belongs to integrated farming practice and the last one for the conventional farming practices. Such results were obtained because of organic farms manage to get enough high yields and consumers prefer to purchase organic vegetables.

The production of fruits and berries occupy the same places according all farming practices analysed: the first place belongs to conventional farming practice. The second place belongs to integrated farming practice and the last one for the organic farming practices. Such situation is caused by higher production costs for the organic fruits and berries, which are inadequate for prices received.

It is important to pay attention that support is not included in to multi-criteria analysis as a criterion. It is made not by coincidence, but on purpose to reveal real picture of the performance of different farming practices analyzed. In order to achieve the goals, policy makers could to project the need for support and strategically direct it to stimulate development of desirable farming practices. Moreover research results are useful if support will be abolished.

Summarising it is worth to say that three methods (SAW, COPRAS and TOPSIS) present almost the same ranks for farming practices. VIKOR method presents almost different means due to methodological issues concerning the compromise solution, based on mutual concessions.

According to the selected criterions (yield, share of sold production, expenses for plant protection, production cost, price and labour input) potatoes, fruits and berries both conventional and integrated farming practices has obtained the same rank (1-2) in Lithuania. Organic farming practice has shown worse rank. However, detailed analysis shows that organic farming practices only for vegetables is the most suitable. One can conclude, that the prices of organic production are comparatively too low. Their changes would influence changes in ranks.

\section{Conclusion}

Theoretically, organic and integrated farming practices had potentially higher positive influence to soil quality and lower negative environmental impact than the conventional farming practice. When comparing with the conventional and integrated farming practices, the 
organic farming practice achieves higher profitability and greater energy efficiency. Organic farming reveals to be either superior or similar to integrated farming practice in environmental terms.

Scientific literature suggests the methodology for the evaluation of organic and integrated farming practices using technological, economic and social indicators has to be created according multi-criteria analysis methods. Almost the same ranks obtained for farming practices of three methods (SAW, COPRAS and TOPSIS) ensure reliable results of this paper.

Traditionally, potatoes, vegetables and orchards are mostly cultivated under the conventional farming practice. In contrary, half of berry plantations are cultivated under the organic farming practice. The reasons are mainly related to higher profitability farming conventionally.

Comparatively new (starting 2012) integrated farming practice covers only potatoes, vegetables, fruits and berries, because of lack of financial funds for all other crops.

Potatoes, fruits and berries under both conventional and integrated farming practices has obtained the same rank (1-2) according to the selected criterions (yield, share of sold production, expenses for plant protection, production cost, price and labour input). Organic farming practice has shown worse rank. Organic farming practice has appeared the most suitable for vegetables. Prices of organic production are comparatively too low. Their changes would influence changes in ranks.

\section{References}

Acs, S., Hanley, N., Dallimer, M., Gaston, K. J., Robertson, P., Wilson, P., and Armsworth, P. R. (2010). The effect of decoupling on marginal agricultural systems: Implications for farm incomes, land use and upland ecology. Land use Policy, 27(2), 550-563.

Balana, B. B., Vinten, A., and Slee, B. (2011). A review on cost-effectiveness analysis of agri-environmental measures related to the EU WFD: Key issues, methods, and applications. Ecological Economics, 70(6), 1021-1031.

Balas, M. M. (2014). Seven passive greenhouse synergies. Acta Polytechnica Hungarica, 11(4), 199-210.

Baležentis, T., Štreimikienè, D., Melnikienè, R., \& Yu, Z. (2017). Non-parametric analysis of yield risk in Lithuanian crop farming. Journal of Business Economics and Management, $18(3), 521-536$.

Balezentis, T. (2014). On measures of the agricultural efficiency - a review. Transformation in Business \& Economics, 13(3).

Baležentis, T. (2016). Stochastic production frontier for the Lithuanian family farms. Journal of Business Economics and Management, 17(2), 283-298.

Blanco Fonseca, M. (2007). Advanced modeling tools for integrated assessment of water and agricultural policies. Water and Sustainability Development in the Mediterranean. 3rd Regional Workshop on Water and Sustainable Development in the Mediterranean, Zaragozza. 19-21.

Craheix, D., Angevin, F., Doré, T., and De Tourdonnet, S. (2016). Using a multicriteria assessment model to evaluate the sustainability of conservation agriculture at the cropping system level in France. European Journal of Agronomy, 76, 75-86.

Crowder, D. W., and Reganold, J. P. (2015). Financial competitiveness of organic agriculture on a global scale. Proceedings of the National Academy of Sciences, 112(24), 76117616. 
Czyżewski, A., \& Smędzik-Ambroży, K. (2015). Specialization and diversification of agricultural production in the light of sustainable development. Journal of International Studies, 8(2), 63-73

De Luca, A. I., Iofrida, N., Leskinen, P., Stillitano, T., Falcone, G., Strano, A., and Gulisano, G. (2017). Life cycle tools combined with multi-criteria and participatory methods for agricultural sustainability: insights from a systematic and critical review. Science of The Total Environment, 595, 352-370.

Delmotte, S., Barbier, J. M., Mouret, J. C., Le Page, C., Wery, J., Chauvelon, P., Sandoz, A., and Ridaura, S. L. (2016). Participatory integrated assessment of scenarios for organic farming at different scales in Camargue, France. Agricultural Systems, 143, 147-158.

Dzikowski, P. (2013). The impact of information sources for innovation on stimulating innovation activity of food and beverage manufacturers in Western Poland. In: Business development opportunities (ed.), Kardas J. S., Brodowska-Szewczuk J., University of Natural Sciences and Humanities Publishing House, Siedlce, 117-125.

EU Regulation No 1305/2013 of the European Parliament and of the Council of 17 December 2013 On support for rural development by the European Agricultural Fund for Rural Development (EAFRD) and repealing Council Regulation (EC) No 1698/2005.

Eurostat database (2017). Retrieved June 19, 2017, from http://ec.europa.eu/eurostat/data/database.

Giupponi, C., Azzellino, A., Salvetti, R., Parati, P., Carpani, M. (2012). Water quality assessment in the Venice lagoon watershed with multiple modelling approaches. Managing Resources of a Limited Planet: Pathways and Visions Under Uncertainty.International Environmental Modelling and Software Society, Leipzig, Germany, 1327-1334.

Hwang, C. L., Yoon, K. (1981). Multiple Attribute Decision Making: Methods and Applications a State of the Art Survey. Berlin: Springer-Verlag.

Informacija apie 2016 metais Lietuvoje deklaruotas žemès ūkio naudmenas ir kitus plotus (2016). Vilnius: Valstybès įmonè Žemès ūkio informacijos ir kaimo verslo centras.

Jouzi, Z., Azadi, H., Taheri, F., Zarafshani, K., Gebrehiwot, K., Van Passel, S., and Lebailly, P. (2017). Organic Farming and Small-Scale Farmers: Main Opportunities and Challenges. Ecological Economics, 132, 144-154.

Kamali, F. P., Borges, J. A., Meuwissen, M. P., de Boer, I. J., and Lansink, A. G. O. (2017). Sustainability assessment of agricultural systems: The validity of expert opinion and robustness of a multi-criteria analysis. Agricultural Systems, 157, 118-128.

Kirchmann, H., Bergström, L. (2008). Organic crop production: Ambitions and limitations. Dordrecht, The Netherlands: Springer.

Kirchmann, H., Kätterer, T., Bergström, L., Börjesson, G., and Bolinder, M. A. (2016). Flaws and criteria for design and evaluation of comparative organic and conventional cropping systems. Field Crops Research, 186, 99-106.

Kriščiukaitienè, I., Juškevičienè, D., Galnaitytè, A., Eirošius, Š., Kuliešis, G., and Namiotko, V. (2013). 2014-2020 m. Kaimo plètros priemoniu išmoku dydžiu modeliavimas. Studija. Vilnius: LAEI.

Kriščiukaitienè, I., Namiotko, V., and Koç, A. A. (2015). The assessment of agricultural sector in Turkey and selected EU countries. Management Theory and Studies for Rural Business and Infrastructure Development, 37(1), 95-102.

Lietuvos žemès ūkis 2015 (2016). Vilnius: Lietuvos statistikos departamentas.

Manos, B. (2016). A Decision Support System for Multiple Criteria Alternative Ranking Using TOPSIS and VIKOR: A Case Study on Social Sustainability in Agriculture. In: Decision Support Systems VI-Addressing Sustainability and Societal Challenges: 2nd 
International Conference, ICDSST 2016, Plymouth, UK, May 23-25, 2016, Proceedings 250, Springer.

Nemecek, T., Dubois, D., Huguenin-Elie, O., and Gaillard, G. (2011). Life cycle assessment of Swiss farming systems: I. Integrated and organic farming. Agricultural Systems, 104(3), 217-232.

Opricovic, S., and Tzeng, G. H. (2004). Compromise solution by MCDM methods: A comparative analysis of VIKOR and TOPSIS. European Journal of Operational Research, 156(20), 445-455.

Pacini, C., Wossink, A., Giesen, G., Vazzana, C., and Huirne, R. (2003). Evaluation of sustainability of organic, integrated and conventional farming systems: a farm and fieldscale analysis. Agriculture, Ecosystems \& Environment, 95(1), 273-288.

Peigné, J., Casagrande, M., Payet, V., David, C., Sans, F. X., Blanco-Moreno, J. M., Cooper, J., Gascoyne, K., Antichi, D., Bàrberi, P., Bigongiali, F., Surböck, A., Kranzler, A., Beeckman, A., Willekens, K., Luik, A., Matt, D., Grosse, M., Heß, J., Clerc, M., Dierauer, H., and Mäder, P. (2016). How organic farmers practice conservation agriculture in Europe. Renewable Agriculture and Food Systems, 31(1), $72-85$.

Petit, C., and Aubry, C. (2016). Typology of organic management styles in a cash-crop region using a multi-criteria method. Organic Agriculture, 6(3), 155-169.

Posner, J. L., Baldock, J. O., Hedtcke, J. L. (2008). Organic and Conventional Production Systems in the Wisconsin Integrated Cropping Systems Trials: I. Productivity 19902002. Agronomy Journal, 100(2), 253-260.

Rajnoha, R., and Lesníková, P. (2016). Strategic Performance Management System and Corporate Sustainability Concept-Specific Parametres in Slovak Enterprises. Journal of Competitiveness, 8(3), 107-124.

Reganold, J. P., Glover, J. D., Andrews, P. K., and Hinman, H. R. (2001). Sustainability of three apple production systems. Nature, 410(6831), 926-930.

Reiff, M., Surmanová, K., Balcerzak, A. P., \& Pietrzak, M. B. (2016). Multiple criteria analysis of European Union agriculture. Journal of International Studies, 9(3), 62-74.

Rozman, Č., Grgić, Z., Maksimović, A., Ćejvanović, F., Puška, A., and Šakić Bobić, B. (2016). Multiple-criteria approach of evaluation of milk farm models in Bosnia and Herzegovina. Mljekarstvo, 66(3), 206-214.

Rural Development Programme for Lithuania 2014-2020 (version 3.1). (2017). Approved by the European Commission on the $13^{\text {th }}$ February 2015 by the Decision No C(2015)842 (Last modified by the European Commission on the $14^{\text {th }}$ February 2017 by the Decision No C(2017)116).

Sauer, J., Walsh, J., Zilberman, D. (2012). Producer behaviour and agri-environmental policies: A directional distance based matching approach. 2012 Annual Meeting, August 12-14, 2012, Seattle, Washington (124877). Agricultural and Applied Economics Association.

Smith, L. G., Williams, A. G., and Pearce, B. D. (2015). The energy efficiency of organic agriculture: A review. Renewable agriculture and Food systems, 30(3), 280-301.

Streimikiene, D., \& Bilan, Y. (2015). Review of rural tourism development theories. Transformations in Business \& Economics, 14(2), 21-34.

Tasca, A. L., Nessi, S., and Rigamonti, L. (2017). Environmental sustainability of agri-food supply chains: An LCA comparison between two alternative forms of production and distribution of endive in northern Italy. Journal of Cleaner Production, 140, 725-741.

Udagawa, C., Hodge, I., Reader, M. (2014). Farm level costs of Agri-environment measures: The impact of entry level stewardship on cereal farm incomes. Journal of Agricultural Economics, 65(1), 212-233. 
Ustinovičius, L. (2004). Determination of Efficiency of Investments in Construction. International Journal of Strategic Property Management, 8(1), 25-44.

Uthes, S., Piorr, A., Zander, P., Bieńkowski, J., Ungaro, F., Dalgaard, T., Stolze, M., Moschitz, H., Schader, C., Happe, K., Sahrbacher, A., Damgaard, M., Toussaint, V., Sattler, C., Reinhardt, F.-J., Kjeldsen, C., Casini, L., Müller, K. (2011). Regional impacts of abolishing direct payments: An integrated analysis in four European regions. Agricultural Systems, 104(2), 110-121.

Vico, G., Prodanovic, R., and Bodiroga, R. (2017). A Two-Stage Approach for MultipleCriteria Decision Making In Plant Production. Proceedings: Savetovanje o Biotehnologiji sa međunarodnim učešćem, Čačak.

Zavadskas, E. K., Kaklauskas, A., Vilutiene, T. (2009). Multicriteria evaluation of apartments blocks maintenance contractors: Lithuanian case study. International Journal of Strategic Property Management, 13(4), 319-338.

Žvirblis, A., Buračas, A. (2010). The consolidated measurement of the financial markets development: the case of transitional economies. Technological and economic development of economy: Baltic journal on sustainability, 16(2), 266-279. 